\title{
New Regression Models For Evaluating The Tensile Strength of Some Natural Building Stones Using The Indirect Tensile Tests and P-Wave Velocity
}

\section{Tamer EFE ( $\nabla$ tamer.efe@gmail.com )}

Suleyman Demirel University: Suleyman Demirel Universitesi https://orcid.org/0000-0002-1727-6404

\section{Servet Demirdag}

Suleyman Demirel University: Suleyman Demirel Universitesi

Nazmi Sengun

Suleyman Demirel University: Suleyman Demirel Universitesi

\section{Kenan Tufekci}

Uludag University: Bursa Uludag Universitesi

\section{Rasit Altindag}

Suleyman Demirel University: Suleyman Demirel Universitesi

\section{Research Article}

Keywords: Natural building stone, Uniaxial tensile strength, Brazilian test, Bending tests, P-wave velocity, Linear regression analysis

Posted Date: October 25th, 2021

DOI: https://doi.org/10.21203/rs.3.rs-876281/v1

License: (c) (1) This work is licensed under a Creative Commons Attribution 4.0 International License. Read Full License 


\section{Abstract}

In this study, experimental and statistical analyses were conducted to determine the relationship between the direct and indirect tensile strength values of rocks used as a natural building stone. Brazilian disc method, 3 and 4-point bending tests were chosen as indirect methods. In addition to the tensile tests, some physico-mechanical properties of the rocks were determined in order to perform multiple regression analysis. According to the analysis, it was concluded that the statistical models including P-wave velocity values are the models that best estimate the uniaxial tensile strength. New empirical formulas have been proposed using P-wave velocity and indirect test results. When the $V_{p}$ was used and thickness/Diameter ratio was set to 1.0 in the Brazilian tensile strength (BTS) test, the coefficient of determination ( $R^{2}$ ) value of the model was found $98.7 \%$. In 3-point bending strength tests performed in accordance with EN standard, the $R^{2}$ value of statistical model including the $V_{p}$ was found $92.6 \%$. In the 4-point bending strength tests, the most suitable dimension was found to be $25 \times 50 \times 150 \mathrm{~mm}$ and the $\mathrm{R}^{2}$ value of the model was found to be $92.8 \%$. As a result, the best regression model including $B T S$ and $V_{p}$ values was proposed to estimate the TS of rocks.

\section{Introduction}

Natural stones have been used as building material in architectural works and monuments since ancient ages. Originally, natural building stone was used for load-bearing masonry walls, but more recently it has been used as curtain walling for high rise buildings (Yates et al. 2012). Natural stones are widely used in flooring, stairs, cladding and decorative purposes due to their property of being a highly resistant building material and their color properties (Cetintas and Akboga 2020). The physical, chemical and mechanical properties of natural stones play an important role in determining the areas where they can be applied as building materials (Karaca 2010). Many different rocks such as granite, marble, limestone, sandstone, travertine, and andesite have been used as natural building material from past to present. Engineers are commonly using the uniaxial compressive strength (UCS) and tensile strength (TS) of rock for many engineering applications. The main problem in determining the strength of rocks is that this process is time consuming and expensive and requires sophisticated test machines and fixtures. For this reason, engineers often prefer to use indirect tests such as Brazilian tensile tests, bending tests, point load index, Schmidt rebound number, and ultrasonic tests to determine the strength of rocks. Sample preparation and application of these indirect tests are easier and cheaper compared to the UCS and TS tests (Kahraman et al. 2012; Raj and Pedram 2015).

TS is one of the primary characteristics of natural stones, which play a crucial role in the planning and project designing of many mining and civil engineering works. Several factors are effective on the TS of rock materials, e.g. discontinuities, lamination, foliation, mineral composition, and porosity. Rocks are less resistant to tension than to compression or shear (Tang et al. 2007; Liu et al. 2019).

Different testing methods have been proposed for the investigation of the tensile properties of rocks. Direct tensile testing of rock provides more exact and reliable results compared to indirect tensile testing. Due to the inherent nature of the tensile test, some undesirable results may occur during application such as bending, torsion, concentrated loads or stress concentration. These factors are usually caused by the alignment of the sample or unsuitable connections between the rock sample and the fixture caps. Therefore, the difficulties related to the direct tensile test application have led to the development of different indirect methods to determine the TS of materials. Brazilian test (ISRM 1978; ASTM D3967-08), 3 and 4-point bending tests (ASTM C880 2015; ASTM C99 2015; TS EN 12372 2007; TS EN 13161 2014), the confined tensile test (Hoek and Brown 1980) and the ring test (Hobbs 1965) have been used as indirect methods since they are easy-to-apply and low-cost methods for many years.

There are many different studies on determination of the tensile strength using direct and indirect testing methods. In some of these studies, it is stated that it is not appropriate to use indirect methods. The generally accepted view is that 
the most widely used method is the BTS test and it is more practical to use this test instead of the Uniaxial tensile strength (UTS) test. The BTS test is the most widely used indirect method for reasons such as ease of sample preparation, cheapness and simplicity. Many different researchers indicate that the values acquired from BTS test are higher than the UTS values. However, some researchers stated that the BTS test is not a suitable method for determining the TS because the test sample breaks under biaxial stress conditions (Fairhust 1964; Chen and Stimpson 1993; Erarslan and Williams 2012; Li and Wong 2013; Komurlu et al. 2017). In the study conducted by Fahimifar and Malekpour (2012), the suitable test conditions for the Brazilian test were proposed to obtain the closest results to the direct tensile test. Li and Wong (2013) stated that the stress occurring in the sample in the Brazilian test is not uniaxial. Therefore, they emphasized that tensile stress in rocks could be overestimated. Briševac et al. (2015) stated that numerous scientific studies have been carried out regarding the TS of materials and the BTS test, however, there have been still no practical approaches available. Researchers offered that a new approach or correction coefficients should be developed that would allow the accurate determination of the TS values of the rocks by using the Brazilian test. Perras and Diederichs (2014) suggested that the BTS should be corrected by multiplying a coefficient of 0.7-0.9 depending on the rock type. Because of the testing configuration and variability of test specimens, there is no general agreement about how to estimate the TS of rocks (Perras and Diederichs 2014). Some hybrid models have been proposed by Mahdiyar et al. (2019) to estimate the tensile strength of rocks using statistical methods. Moreover, some researchers proposed that the bending tests should be performed to determine the TS of material (Jaeger et al. 2007). Efe et al. (2019) studied the effect of sample dimension on 3- and 4-point bending tests of marble and its relationship with direct tensile strength test. In another study conducted by Efe et al. (2021), new correction coefficients were proposed to be able to estimate the direct tensile strength from BTS and bending strength tests. According to the results of that study, the coefficients were found to be 0.50 for BTS, 0.33 for the 3-point bending tests and 0.40 for the 4-point bending tests.

When the literature is examined, it is obvious that the results obtained from indirect methods do not always correctly predict the UTS value. In fact, the results obtained by indirect methods actually represent the TS value of the rock material that has been investigated for 70 years (Efe et al. 2021). In literature, it is seen that there is no general agreement on a test method which is suitable for rocks and rock-like materials (Efe et al. 2021). While determining the TS from indirect methods, the sample is not in a uniform state of stress as it is in the UTS. Therefore, when calculating the TS of rock materials using indirect tests, it may be useful to consider some rock properties such as P-wave velocity, density, porosity and unit volume weight. P-wave velocity has a crucial role in the determination of structural properties of the rock as it is related to the void and fracture-crack systems within the rocks. In addition, this method can be applied as a quick, simple, cheap, and non-destructive test in the laboratory and the field (Moradian and Behnia 2009). However, there are very few studies on the estimation of the mechanical properties of rocks using the ultrasonic test method. Rio et al. (2006) determined the characterization of granites using acoustic techniques on different samples obtained from many quarries. Yagız (2011) estimated the properties of rock such as the uniaxial compressive strength, modulus of elasticity, Schmidt hardness, slake durability index, water absorption and effective porosity, and saturated and dry density using the $V_{p}$. Uyanik et al. (2019) determined the physical and mechanical properties of rocks with the help of multi-parameter experimental relationships obtained by using a combination of P- and S-wave velocities. Garia et al. (2019) conducted a study based on laboratory measurements to find the interdependence between petrophysical properties and ultrasonic wave velocities. The propagation of seismic wave in the intact and jointed rocks subjected to triaxial loading condition was investigated by Liu et al. (2019) experimentally. Based on that field investigation, it was found that joint has a significant attenuation effect on seismic P-wave. In the light of the literature, it can be concluded that the research to estimate the TS value from ultrasonic methods is meager.

The main goal of this study is to investigate the predictability of the UTS of natural building stones using BTS, 3- and 4point bending strength tests and physical-mechanical rock properties especially the P-wave velocity. To this aim, 9 different rock types (sedimentary, metamorphic and magmatic origin) used as natural building stone in the construction industry were tested. The test results were analyzed with statistical methods and the UTS values were correlated with the 
corresponding indirect tests and physical rock properties. As a result of the experimental studies, it was tried to reveal which indirect method would be more appropriate to use while determining the UTS value, as well as whether the physical properties of the rocks could be considered in combination with the indirect methods.

\section{Materials And Methods Experimental procedure}

In order to predict the TS of rocks from indirect tests, 9 different natural stones obtained from various locations of Turkey were examined. Tested rock types were given in Table 1 . These rocks have been chosen because they have been widely used as a construction material. Direct tensile test sample preparation and testing methods were carried out in accordance with ASTM. Brazilian, 3 and 4-point bending tests were conducted according to ISRM, ASTM and TS EN standards. All rock samples used in these experiments were obtained from the same rock block and also same electromechanical test device which is computer controlled and with $100 \mathrm{kN}$ capacity (Fig. 1) was used in direct and indirect tensile tests.

Table 1

Rocks used in the tests

\begin{tabular}{|lllll|}
\hline Rock code & Rock type & Origin & Location \\
\hline L & Limestone & Sedimentary & Egirdir/Isparta \\
\hline AL & Limestone (Lymra) & Sedimentary & Finike/Antalya \\
\hline DL & Dolomitic limestone & Sedimentary & Burdur \\
\hline FCM & Marble (fine crystalline) & Metamorphic & Afyon \\
\hline CCM & Marble (coarse crystalline) & Metamorphic & Manyas/Balıkesir \\
\hline T & Tuff & Igneous & Afyon \\
\hline A & Andesite & Igneous & Isparta \\
G & Granite & Igneous & Yaylak/Aksaray \\
D & Diabase & Igneous & Alanya/Antalya \\
\hline
\end{tabular}

\section{Physical properties of rocks}

The unit volume weight, apparent and total porosity tests were performed according to TS EN 1936 (2006) standard. In these experiments, 10 cubic samples were used (Fig. 4). Pundit 7 tester is the P-wave transmission method consists of a pulser and a receiver which are piezoelectric transducers placing on two opposite and parallel sides of the samples. The travel time is measured through the exact distance between the transducers and the wave propagation velocity. P-wave velocity measurements of the rocks were carried out according to the standard of ASTM D2845 (2017) by using 10 samples in the form of a cube (Fig. 4). The propagation velocities of the compression waves $\left(V_{p}\right)$ is calculated as given in Eq. 1.

Where $V_{p}$ is the pulse-propagation velocity, $(\mathrm{km} / \mathrm{s}), \mathrm{L}$ is the pulse-travel distance, $(\mathrm{km})$ and $T$ is the effective pulse-travel time, s.

\section{Mechanical properties of rocks}


The uniaxial compressive strength (UCS) tests were carried out in accordance with ISRM (2007) suggested methods. UCS experiments were carried out by using 10 circular cylinders having a diameter approximately $54 \mathrm{~mm}$. The UCS was calculated by dividing the maximum load carried by the specimen during test, by the cross-sectional area.

Direct tensile strength tests were performed by considering the methods proposed by ASTM D2936 (2008) and ISRM. For 9 different rock types, 6 pieces of prismatic rock samples of 120x120x250 mm in size were prepared on a lathe with the geometric form shown in Fig. 2(A). At least 6 dumbbell shaped samples from each rock types were used and the loading rate was determined as $5-15 \mathrm{~N} / \mathrm{s}$.

BTS test is recommended as an indirect tensile test method in rocks by ISRM (1978) and ASTM (2008). According to the ASTM D 3967 (2008) standard, the loading speed is between 0.05 and $0.35 \mathrm{MPa} / \mathrm{s}$, and the (t / D) ratio is between 0.2 and 0.75 . According to the method proposed by ISRM (2007), the thickness should be equal to the radius and the loading speed should be $200 \mathrm{~N} / \mathrm{s}$. In this study, the tests were carried out in 3 different thickness/diameter (t/D) ratios of $0.5,0.75$ and 1.0. Disc samples having of $54 \mathrm{~mm}$ diameter were prepared and at least 10 samples were used with different thickness (27 mm, $41 \mathrm{~mm}$ and $54 \mathrm{~mm}$ ) (Fig. 2). A loading speed of $200 \mathrm{~N} / \mathrm{s}$ was chosen. The BTS is calculated with the help of Eq. (2).

where, $\mathrm{F}$ is the maximum applied load, $\mathrm{D}$ is the sample (disc) diameter and $\mathrm{t}$ is the sample thickness.

The bending tests can be used to determine indirect tensile strength of rocks. It creates both tensile stress and compression stress fields in bending tests. Stress and displacement distributions are found by basic beam theory (Jaeger et al. 2007). The measured stress at the moment when the tensile stress reaches the TS of the material is called "flexural strength". 3-point bending strength (3PBS) tests were carried out in accordance with EN 12372 (2007) (flexural strength under concentrated load) and ASTM C 99 (2015). In this study, as shown in Fig. 3(A), 3PBS tests were carried out on samples of $50 \times 50 \times 300 \mathrm{~mm}$ and $25 \times 50 \times 150 \mathrm{~mm}$ in accordance with EN standards. In the ASTM standard, the recommended sample size for the 3PBS test is $57.2 \times 101.6 \times 203.2 \mathrm{~mm}$. The loading rate was chosen as $0.25 \pm 0.05$ $\mathrm{MPa} / \mathrm{s}$ for EN tests and $74 \mathrm{~N} / \mathrm{s}$ for ASTM tests. The sample sizes selected for the 3PBS experiments and the positions of the supports are shown in Fig. $3(\mathrm{~A})$ in detail.

4-point bending strength (4PBS) tests were also carried out in accordance with EN 13161 (2014) (flexural strength under constant moment) and ASTM 880 - 98 (2015). Dimensions of the samples (Fig. 3B), the distance between the supports and loading rates are same as in EN 12372. According to ASTM standard, the specimens should be approximately $32 \times 102 \times 381 \mathrm{~mm}$ size and the loading rate should be $70 \mathrm{kPa} / \mathrm{s}$.

The 3PBS is calculated by the formula in Eq. (3) and the 4PBS is calculated from Eq. 4 according to EN standard and Eq. 5 according to ASTM standard. 
Where the $F$ was measured as the maximum applied force, / is the length of span, $b$ is the width of specimen, $h$ is the thickness of specimen.

\section{Linear regression analyses}

Regression analysis is used to examine the relationship between the dependent variable and one or more independent variables. It is called simple (univariate) regression analysis if one independent variable is used, and multiple (multivariate) regression analysis if more than one independent variable is used. The simple regression model that explains the linear relationship between the dependent variable and the independent variable is as follows (Eq. 6) (Montgomery and Runger 2013).

Where; Y: dependent variable, : : the intercept of the regression line with the y-axis, : slope of the regression line, independent variable. In the simple regression analysis performed in this study, UTS was chosen as the dependent variable, and indirect TS values were assumed as the independent variable.

Multiple linear regression analysis was performed using MINITAB 16. In this analysis, it is aimed to explain the relationship between variables functionally and to define this relationship with a model. The multiple linear regression equation is expressed in Eq. 7 with respect to the population for a number of independent variables (Montgomery and Runger 2013).

Where; : the effect when the independent variables have taken the zero value, : the partial effect of 1 unit change in independent variable $\left(X_{1}\right)$ on dependent variable, : the partial effect of 1 unit change in independent variable $\left(X_{2}\right)$ on dependent variable.

UTS was selected as the dependent variable in multiple linear regression analysis. Data obtained from all other indirect methods $\left(\sigma_{\mathrm{tBrez}}, \sigma_{3 \mathrm{PBS}}, \sigma_{4 \mathrm{PBS}}\right)$ and physical and mechanical tests (UVW, AP, 『por, $\mathrm{V}_{\mathrm{p}}$, and UCS) were assumed as independent variables. Mean values of 9 rocks were used in analyses. In the multiple regression models, the model with the highest coefficient of determination $\left(R^{2}\right)$ (closest to 1 ) was tried to be found.

\section{Experimental Results}

\section{Test results for physical properties}

Physical properties of tested rocks are given in Table 2. It is seen that the rock with the highest unit volume weight is diabase and the rock with the lowest unit volume weight is tuff. The total porosity (囚por) values of limestone and fine crystalline marble were found below $1.0 \%$. Total porosity values of tuff and andesite were determined as $39.5 \%$ and $12.3 \%$, respectively. $V_{p}$ values of rocks were found low for high porosity rocks and high for low porosity rocks. Also the highest $V_{p}$ values were found in limestone and dolomitic limestone samples, and the lowest values were found in tuff samples. The rocks with the highest UCS are granite and diabase, while the rocks with the lowest UCS are tuff, coarse crystalline marble and limestone (lymra), respectively. 
Table 2

Physical properties of rocks

\begin{tabular}{|c|c|c|c|c|c|c|c|c|}
\hline Sample & UVW & & $\mathrm{AP}$ & & 囚por & & $V_{p}$ & \\
\hline \multirow[t]{2}{*}{ Code } & $\left(\mathrm{g} / \mathrm{cm}^{3}\right)$ & & (\%) & & (\%) & & $(\mathrm{km} / \mathrm{s})$ & \\
\hline & Mean & SD & Mean & SD & Mean & SD & Mean & SD \\
\hline
\end{tabular}

\begin{tabular}{|lllllllll|}
\hline L & 2.708 & 0.001 & 0.104 & 0.022 & 0.479 & 0.023 & 6.361 & 0.051 \\
\hline AL & 2.472 & 0.002 & 7.929 & 0.020 & 9.748 & 0.086 & 3.924 & 0.083 \\
\hline DL & 2.736 & 0.035 & 1.252 & 0.336 & 4.493 & 1.228 & 6.261 & 0.368 \\
\hline FCM & 2.720 & 0.004 & 0.134 & 0.020 & 0.381 & 0.158 & 5.301 & 0.250 \\
\hline CCM & 2.715 & 0.001 & 0.174 & 0.023 & 1.093 & 0.041 & 4.827 & 0.203 \\
\hline T & 1.485 & 0.007 & 30.852 & 0.473 & 39.521 & 0.286 & 2.436 & 0.089 \\
\hline A & 2.333 & 0.020 & 5.779 & 0.463 & 12.318 & 0.756 & 4.935 & 0.046 \\
\hline G & 2.644 & 0.004 & 0.484 & 0.019 & 1.023 & 0.153 & 5.215 & 0.081 \\
\hline D & 2.961 & 0.019 & 1.471 & 0.136 & 2.744 & 0.624 & 5.136 & 0.232 \\
\hline UVW: Unit volume weight (Apparent density), AP: Apparent porosity. \#por: Total porosity, $V_{p}:$ P-wave velocity \\
\hline
\end{tabular}

\section{Mechanical test results of rocks}

UCS, UTS and BTS test results are presented in Table 3. The rocks with the highest UCS are granite and diabase, while the rocks with the lowest UCS are tuff, coarse crystalline marble and limestone (lymra), respectively. 
Table 3

Mechanical properties of rocks

\begin{tabular}{|c|c|c|c|c|c|c|c|c|c|c|}
\hline \multirow{3}{*}{$\begin{array}{l}\text { Sample } \\
\text { Code }\end{array}$} & \multirow{2}{*}{\multicolumn{2}{|c|}{$\sigma_{U c S}(\mathrm{MPa})$}} & \multirow{2}{*}{\multicolumn{2}{|c|}{$\sigma_{U T S}(\mathrm{MPa})$}} & \multicolumn{6}{|c|}{$\sigma_{\mathrm{tBrez}}(\mathrm{MPa})$} \\
\hline & & & & & \multicolumn{2}{|c|}{$t / D=0.50$} & \multicolumn{2}{|c|}{$t / D=0.75$} & \multicolumn{2}{|c|}{$t / D=1.0$} \\
\hline & Mean & SD & Mean & SD & Mean & SD & Mean & SD & Mean & SD \\
\hline L & 121.15 & 14.54 & 1.56 & 0.15 & 7.68 & 0.84 & 7.94 & 1.34 & 6.58 & 1.08 \\
\hline$A L$ & 77.14 & 7.73 & 3.45 & 0.9 & 5.34 & 0.73 & 5.82 & 0.44 & 5.88 & 0.59 \\
\hline DL & 119.28 & 13.62 & 3.29 & 0.96 & 8.59 & 2.08 & 7.8 & 1.55 & 8.67 & 2.78 \\
\hline FCM & 77.78 & 6.74 & 3.19 & 0.61 & 7.68 & 0.87 & 7.72 & 1.13 & 7.08 & 1.57 \\
\hline $\mathrm{CCM}$ & 60.41 & 8.18 & 2.84 & 0.57 & 5.23 & 0.6 & 5.44 & 0.7 & 5.58 & 0.7 \\
\hline $\mathrm{T}$ & 19.38 & 2.15 & 1.36 & 0.32 & 2.05 & 0.24 & 1.94 & 0.25 & 2.07 & 0.16 \\
\hline$A$ & 88.55 & 12.88 & 4.88 & 1.07 & 9.4 & 0.89 & 9.63 & 0.78 & 9.29 & 0.99 \\
\hline G & 149.06 & 18.37 & 5.27 & 1.11 & 9.54 & 0.68 & 10.85 & 0.92 & 10.06 & 1.2 \\
\hline$D$ & 146.08 & 21.82 & 8.87 & 2.89 & 15.87 & 1.26 & 16.09 & 1.66 & 15.31 & 1.8 \\
\hline
\end{tabular}

When the results are examined, it is seen that the TS values in igneous rocks such as granite and diabase are relatively high as in the UCS experiments. Although tuff is igneous in origin, it is a "very low strength" rock according to UCS class. BTS values were found to be quite higher than UTS values, and the BTS/UTS ratio is between 1.5-2.6 for all rocks except for limestone. This ratio was found to be approximately 5 in limestone due to fissures and cracks. These discontinuities were not effective on the result in the BTS tests compared to UTS tests. For this reason, using the results obtained from indirect tests instead of UTS values in rocks containing discontinuities may be erroneous.

According to the bending strength test results (Table 4), the lowest values were obtained in tuff samples and the highest values were found in diabase samples. Generally, 3PBS results were higher than other direct and indirect tensile test results. 
Bending strength test results

\begin{tabular}{|c|c|c|c|c|c|c|c|c|c|c|c|c|}
\hline \multicolumn{7}{|c|}{3 Point Bending Strength (MPa) } & \multicolumn{6}{|c|}{4 Point Bending Strength (MPa) } \\
\hline Sample & $(\mathrm{EN})$ & & & & (ASTM & & $(\mathrm{EN})$ & & & & (ASTN & \\
\hline \multirow[t]{2}{*}{ Code } & \multicolumn{2}{|c|}{$\begin{array}{l}50 \times 50 \times 300 \\
\mathrm{~mm}\end{array}$} & \multicolumn{2}{|c|}{$\begin{array}{l}25 \times 50 \times 150 \\
\mathrm{~mm}\end{array}$} & \multicolumn{2}{|c|}{$57.2 \times 101.6 \times 203.2 \mathrm{~mm}$} & \multicolumn{2}{|c|}{$\begin{array}{l}50 \times 50 \times 300 \\
\mathrm{~mm}\end{array}$} & \multicolumn{2}{|c|}{$\begin{array}{l}25 \times 50 \times 150 \\
\mathrm{~mm}\end{array}$} & \multicolumn{2}{|c|}{$\begin{array}{l}32 \times 102 \times 381 \\
\mathrm{~mm}\end{array}$} \\
\hline & Mean & SD & Mean & SD & Mean & SD & Mean & SD & Mean & SD & Mean & SD \\
\hline L & 8.73 & 1.54 & 10.49 & 1.53 & 8.66 & 1.6 & 7.9 & 1.83 & 7.34 & 1.48 & 7.5 & 1.13 \\
\hline $\mathrm{AL}$ & 9.57 & 1.21 & 10.4 & 0.89 & 8.91 & 0.88 & 8.75 & 1.18 & 7.85 & 0.92 & 8.27 & 0.49 \\
\hline DL & 10.38 & 2.51 & 10.71 & 1.91 & 9.59 & 3.05 & 8.19 & 0.99 & 7.88 & 1.32 & 7.58 & 2.2 \\
\hline FCM & 15.8 & 4.04 & 12.94 & 1.17 & 14.26 & 1.69 & 10.68 & 0.93 & 8.33 & 0.93 & 13.38 & 0.98 \\
\hline CCM & 8.81 & 0.71 & 10.04 & 0.42 & 9.24 & 1.03 & 7.32 & 0.72 & 8.19 & 0.88 & 8.35 & 0.78 \\
\hline $\mathrm{T}$ & 3.81 & 0.29 & 3.73 & 0.33 & 3.72 & 0.35 & 2.52 & 0.5 & 2.77 & 0.14 & 2.89 & 0.32 \\
\hline$A$ & 16.78 & 1.04 & 15.42 & 1.39 & 12.6 & 1.26 & 13.95 & 1.12 & 13.82 & 1.48 & 12.12 & 0.79 \\
\hline G & 16.63 & 1.15 & 13.55 & 1.59 & 13.34 & 1.1 & 11.6 & 1.56 & 13.2 & 1.43 & 14.15 & 1.36 \\
\hline D & 21.64 & 1.34 & 22.71 & 2.14 & 20.38 & 2.17 & 18.98 & 2.12 & 18.2 & 2.3 & 19.26 & 1.48 \\
\hline
\end{tabular}

As a result of all tests, it was seen that none of the indirect tensile strength values correctly predict the UTS value. It seems that there is a need for new approaches including other rock properties to estimate UTS from indirect tests. For this reason, multivariate regression analysis including other material properties of rocks has been needed.

\section{Discussion}

Within the scope of this study, TS values of different types of rocks were determined by direct and indirect methods. As can be seen in Fig. 5, when the results are compared, it is seen that the strength values are quite different from each other. According to the literature, it is observed that similar results have been reported by different researchers in different studies (Pandey and Singh 1986; Coviello et al. 2005; Erarslan and Williams 2012; Li and Wong 2013; Unlu and Yilmaz 2014; Efe et al. 2021). For this reason, in order to find the most appropriate indirect method and model which can predict the UTS of the rocks, statistical analysis including the physical and mechanical properties of the rocks have been conducted. For this purpose, simple and multiple linear regression analyses were performed using MINITAB 16.

Simple regression between BTS and UTS was shown in Fig. 6 and simple regression between 3PBS-4PBS and UTS was shown in Fig. 7. $\mathrm{R}^{2}$ (coefficient of determination) values were found to be approximately $0.80-0.87$ for $\mathrm{BTS}, 0.79-0.86$ for 3PBS and 0.81-0.89 for 4PBS, respectively.

Summary of multiple regression analyses are given in Table 5. Comparison of $\mathrm{R}^{2}$ values are given in Fig. 8. According to the results of linear regression analysis, $\mathrm{R}^{2}$ values obtained from multiple regression analyses were higher than simple regression. When estimating the UTS value, it has been found that it is more appropriate to use multiple regressions that contain physical properties and UCS values. In general, statistical models including $V_{p}$ values have been more successful than others in predicting the UTS values of rocks. P-wave velocity is a feature related to the void, porosity and crack systems within the rocks and can provide information about the whole mass of the rock. Therefore, it was determined that $\mathrm{R}^{2}$ values increased by $3 \%-14.2 \%$ compared to simple regression analyses. 
Table 5

Summary of multiple regression analyzes*

\begin{tabular}{|c|c|c|c|c|c|}
\hline $\begin{array}{l}\text { Independent } \\
\text { variable_1 }\end{array}$ & $\begin{array}{l}\text { Independent } \\
\text { variable_2 }\end{array}$ & $\begin{array}{l}\mathrm{R}^{2} \\
(\%)\end{array}$ & $\begin{array}{l}\mathrm{R}^{2} \\
\text { (adj) } \\
(\%)\end{array}$ & $\begin{array}{l}\text { Regression } \\
P\end{array}$ & Regression equation \\
\hline Brez_0.5 & Vp & 94.2 & 92.3 & 0.000 & UTS $=2.72+0.683$ Brez_0.5-0.867 Vp \\
\hline Brez_0.75 & $\mathrm{Vp}$ & 94.4 & 92.6 & 0.000 & $\begin{array}{l}\text { UTS }=2.43+0.649 \text { Brez_0.75-0.780 } \\
\text { Vp }\end{array}$ \\
\hline Brez_1.0 & Vp & 98.7 & 98.2 & 0.000 & UTS $=2.10+0.705$ Brez_1.0-0.764 Vp \\
\hline 3PBS_EN50 & $\mathrm{Vp}$ & 83.3 & 77.8 & 0.005 & UTS $=0.85+0.402$ 3P_EN50-0.404 Vp \\
\hline 3PBS_EN25 & Vp & 92.6 & 90.2 & 0.000 & UTS $=0.82+0.473$ 3P_EN25-0.556 Vp \\
\hline 3PBS_ASTM & $\mathrm{Vp}$ & 86.5 & 82.0 & 0.002 & $\begin{array}{l}\text { UTS }=0.73+0.494 \text { 3P_ASTM }-0.486 \\
\text { Vp }\end{array}$ \\
\hline 4PBS_EN50 & $\mathrm{Vp}$ & 90.6 & 87.5 & 0.001 & UTS $=0.95+0.501$ 4P_EN50-0.424 Vp \\
\hline 4PBS_EN25 & $\mathrm{Vp}$ & 92.8 & 90.4 & 0.000 & UTS $=0.70+0.509$ 4P_EN25-0.365 Vp \\
\hline 4PBS_ASTM & $\mathrm{Vp}$ & 84.5 & 79.3 & 0.004 & $\begin{array}{l}\text { UTS }=0.83+0.460 \text { 4P_ASTM }-0.355 \\
\operatorname{Vp}\end{array}$ \\
\hline Brez_0.5 & 凶por & 83.6 & 78.1 & 0.004 & $\begin{array}{l}\text { UTS }=-1.31+0.610 \text { Brez_0.5 }+0.0412 \\
\text { 『por }\end{array}$ \\
\hline Brez_0.75 & \por & 87.1 & 82.8 & 0.002 & $\begin{array}{l}\text { UTS }=-1.53+0.615 \text { Brez_0.75 + } \\
0.0482 \text { 邓por }\end{array}$ \\
\hline Brez_1.0 & 囚por & 91.2 & 88.2 & 0.001 & $\begin{array}{l}\text { UTS }=-1.72+0.665 \text { Brez_1. } 0+0.0450 \\
\text { Øpor }\end{array}$ \\
\hline 3PBS_EN50 & \por & 82.1 & 76.1 & 0.006 & $\begin{array}{l}\text { UTS }=-1.51+0.409 \text { 3P_EN50 + } \\
0.0342 \text { 『por }\end{array}$ \\
\hline 3PBS_EN25 & 凶por & 90.8 & 87.7 & 0.001 & $\begin{array}{l}\text { UTS }=-2.45+0.484 \text { 3P_EN25 + } \\
0.0491 \text { 『por }\end{array}$ \\
\hline 3PBS_ASTM & \por & 87.1 & 82.8 & 0.002 & $\begin{array}{l}\text { UTS }=-2.50+0.529 \text { 3P_ASTM + } \\
0.0547 \text { 『por }\end{array}$ \\
\hline 4PBS_EN50 & \por & 89.1 & 85.5 & 0.001 & $\begin{array}{l}\text { UTS }=-1.49+0.507 \text { 4P_EN50 + } \\
0.0346 \text { 『por }\end{array}$ \\
\hline 4PBS_EN25 & 冈por & 91.7 & 88.9 & 0.001 & $\begin{array}{l}\text { UTS }=-1.39+0.515 \text { 4P_EN25 + } \\
0.0296 \text { 『por }\end{array}$ \\
\hline 4PBS_ASTM & 邓por & 86.3 & 81.8 & 0.003 & $\begin{array}{l}\text { UTS }=-1.74+0.502 \text { 4P_ASTM + } \\
0.0489 \text { 『por }\end{array}$ \\
\hline Brez_0.5 & AP & 84.0 & 78.6 & 0.004 & $\begin{array}{l}\text { UTS }=-1.37+0.621 \text { Brez_0.5+0.0564 } \\
\text { AP }\end{array}$ \\
\hline Brez_0.75 & AP & 87.2 & 82.9 & 0.002 & $\begin{array}{l}\text { UTS }=-1.53+0.621 \text { Brez_0.75 + } \\
0.0628 \text { AP }\end{array}$ \\
\hline Brez_1.0 & AP & 91.8 & 89.0 & 0.001 & $\begin{array}{l}\text { UTS }=-1.80+0.679 \text { Brez_1.0 }+0.0624 \\
\text { AP }\end{array}$ \\
\hline
\end{tabular}




\begin{tabular}{|c|c|c|c|c|c|}
\hline $\begin{array}{l}\text { Independent } \\
\text { variable_1 }\end{array}$ & $\begin{array}{l}\text { Independent } \\
\text { variable_2 }\end{array}$ & $\begin{array}{l}\mathrm{R}^{2} \\
(\%)\end{array}$ & $\begin{array}{l}\mathrm{R}^{2} \\
\text { (adj) } \\
(\%)\end{array}$ & $\begin{array}{l}\text { Regression } \\
\mathrm{P}\end{array}$ & Regression equation \\
\hline 3PBS_EN50 & AP & 82.4 & 76.6 & 0.005 & $\begin{array}{l}\text { UTS }=-1.57+0.415 \text { 3P_EN50 + } \\
0.0469 \text { AP }\end{array}$ \\
\hline 3PBS_EN25 & AP & 91.3 & 88.4 & 0.001 & $\begin{array}{l}\text { UTS }=-2.52+0.493 \text { 3P_EN25 + } \\
0.0665 \mathrm{AP}\end{array}$ \\
\hline 3PBS_ASTM & AP & 86.5 & 82.0 & 0.002 & $\begin{array}{l}\text { UTS }=-2.40+0.527 \text { 3P_ASTM + } \\
0.0663 \text { AP }\end{array}$ \\
\hline 4PBS_EN50 & AP & 89.7 & 86.2 & 0.001 & $\begin{array}{l}\text { UTS }=-1.57+0.517 \text { 4P_EN50 + } \\
0.0492 \mathrm{AP}\end{array}$ \\
\hline 4PBS_EN25 & AP & 92.3 & 89.8 & 0.000 & $\begin{array}{l}\text { UTS }=-1.50+0.526 \text { 4P_EN25 + } \\
0.0441 \mathrm{AP}\end{array}$ \\
\hline 4PBS_ASTM & AP & 85.6 & 80.8 & 0.003 & $\begin{array}{l}\text { UTS }=-1.61+0.497 \text { 4P_ASTM + } \\
0.0571 \mathrm{AP}\end{array}$ \\
\hline Brez_0.5 & UVW & 83.0 & 77.4 & 0.005 & $\begin{array}{l}\text { UTS }=2.07+0.634 \text { Brez_0.5-1.28 } \\
\text { UVW }\end{array}$ \\
\hline Brez_0.75 & UVW & 85.6 & 80.8 & 0.003 & $\begin{array}{l}\text { UTS }=2.10+0.625 \text { Brez_0.75-1.32 } \\
\text { UVW }\end{array}$ \\
\hline Brez_1.0 & UVW & 90.9 & 87.9 & 0.001 & $\begin{array}{l}\text { UTS }=2.10+0.698 \text { Brez_1.0-1.47 } \\
\text { UVW }\end{array}$ \\
\hline 3PBS_EN50 & UVW & 79.9 & 73.2 & 0.008 & $\begin{array}{l}\text { UTS }=0.04+0.385 \text { 3P_EN50-0.39 } \\
\text { UVW }\end{array}$ \\
\hline 3PBS_EN25 & UVW & 89.8 & 86.4 & 0.001 & $\begin{array}{l}\text { UTS }=1.43+0.500 \text { 3P_EN25-1.45 } \\
\text { UVW }\end{array}$ \\
\hline 3PBS_ASTM & UVW & 85.0 & 79.9 & 0.003 & $\begin{array}{l}\text { UTS }=1.52+0.534 \text { 3P_ASTM }-1.44 \\
\text { UVW }\end{array}$ \\
\hline 4PBS_EN50 & UVW & 87.8 & 83.7 & 0.002 & $\begin{array}{l}\text { UTS }=0.79+0.504 \text { 4P_EN50-0.778 } \\
\text { UVW }\end{array}$ \\
\hline 4PBS_EN25 & UVW & 90.3 & 87.0 & 0.001 & $\begin{array}{l}\text { UTS }=0.24+0.502 \text { 4P_EN25-0.501 } \\
\text { UVW }\end{array}$ \\
\hline 4PBS_ASTM & UVW & 83.3 & 77.7 & 0.005 & $\begin{array}{l}\text { UTS }=1.21+0.482 \text { 4P_ASTM }-0.93 \\
\text { UVW }\end{array}$ \\
\hline Brez_0.5 & UCS & 83.8 & 78.4 & 0.004 & $\begin{array}{l}\text { UTS }=0.038+0.708 \text { Brez_0.5-0.0189 } \\
\text { UCS }\end{array}$ \\
\hline Brez_0.75 & UCS & 89.2 & 85.6 & 0.001 & $\begin{array}{l}\text { UTS }=0.138+0.773 \text { Brez_0.75-0.0269 } \\
\text { UCS }\end{array}$ \\
\hline Brez_1.0 & UCS & 93.5 & 91.3 & 0.000 & $\begin{array}{l}\text { UTS }=-0.186+0.823 \text { Brez_1.0- } \\
0.0252 \text { UCS }\end{array}$ \\
\hline 3PBS_EN50 & UCS & 79.7 & 73.0 & 0.008 & $\begin{array}{l}\text { UTS }=-0.79+0.353 \text { 3P_EN50 + } \\
0.0027 \text { UCS }\end{array}$ \\
\hline 3PBS_EN25 & UCS & 86.0 & 81.4 & 0.003 & $\begin{array}{l}\text { UTS }=-1.15+0.433 \text { 3P_EN25-0.0030 } \\
\text { UCS }\end{array}$ \\
\hline
\end{tabular}

*Dependent variable is UTS 


\begin{tabular}{|c|c|c|c|c|c|}
\hline $\begin{array}{l}\text { Independent } \\
\text { variable_1 }\end{array}$ & $\begin{array}{l}\text { Independent } \\
\text { variable_2 }\end{array}$ & $\begin{array}{l}\mathrm{R}^{2} \\
(\%)\end{array}$ & $\begin{array}{l}\mathrm{R}^{2} \\
\text { (adj) } \\
\text { (\%) }\end{array}$ & $\begin{array}{l}\text { Regression } \\
\text { P }\end{array}$ & Regression equation \\
\hline 3PBS_ASTM & UCS & 81.3 & 75.1 & 0.007 & $\begin{array}{l}\text { UTS }=-1.12+0.429 \text { 3P_ASTM }+ \\
0.0018 \text { UCS }\end{array}$ \\
\hline 4PBS_EN50 & UCS & 86.5 & 82 & 0.002 & $\begin{array}{l}\text { UTS }=-0.698+0.462 \text { 4P_EN50- } \\
0.0006 \text { UCS }\end{array}$ \\
\hline 4PBS_EN25 & UCS & 90.2 & 87 & 0.001 & $\begin{array}{l}\text { UTS }=-0.591+0.513 \text { 4P_EN25- } \\
0.0057 \text { UCS }\end{array}$ \\
\hline 4PBS_ASTM & UCS & 81.6 & 75.5 & 0.006 & $\begin{array}{l}\text { UTS }=-0.64+0.416 \text { 4P_ASTM + } \\
0.0018 \text { UCS }\end{array}$ \\
\hline
\end{tabular}

According to the results, the best estimation model of UTS is given in Eq. 8. As can be seen in the formula, BTS and $V_{p}$ values are used as independent variables. According to multiple linear regression analysis, when the t/D ratio is 1.0 in the BTS test and the $V_{p}(\mathrm{~km} / \mathrm{s})$ values are used, the $R^{2}$ value $(R-S q)$ of the model obtained is $98.7 \%$, the corrected $R^{2}$ value (R$\mathrm{Sq})$ (adj) was found to be $98.2 \%$.

The relationship between the converted UTS (c-UTS) values calculated from Eq. 7 and the UTS test results is given in Fig. 9. It can be seen from Fig. $9(a)$, the model based on BTS-V $V_{p}$ data can be used in practice and the UTS of rocks can be estimated with a high coefficient of determination $\left(R^{2}=0.99\right)$.

If the 3PBS test is used as an indirect method, the model that best describes UTS according to multiple linear regression analysis is given in Eq. 9. When the dimension of the sample is $25 \times 25 \times 150 \mathrm{~mm}$ in the 3PBS_EN test and the $V_{p}$ values are used, the $R^{2}$ value (R-Sq) of the model is $92.6 \%$, the corrected $R^{2}$ value (R-Sq) (adj) was found to be $90.2 \%$. The relationship between the converted UTS (c-UTS) values calculated from Eq. 9 and UTS test results is presented in Fig. 9(b).

If the 4PBS experiment is preferred as an indirect method, the model that best describes UTS according to multiple linear regression analysis is given in Eq. 10. When the dimension of the sample is $25 \times 25 \times 150 \mathrm{~mm}$ in the 4PBS_EN test and the $V_{p}$ values are used, the $R^{2}$ value (R-Sq) of the model is $92.8 \%$, the corrected $R^{2}$ value (R-Sq) (adj) was found to be $90.4 \%$. The relationship between the c-UTS values calculated from Eq. 10 and the UTS test results is shown in Fig. 9(c).

\section{Conclusion}

In this study, it was investigated which regression model could best predict the UTS values of the rocks based on indirect and physical property test results. For this reason, 9 different natural building stones which have different origin such as sedimentary, metamorphic, and igneous were tested. The test results were statistically analyzed and the UTS values were correlated with the corresponding BTS, 3 and 4-points bending and physical properties of rocks.

It was concluded that the TS values obtained from the indirect methods were approximately 2 to 3 times greater than the UTS values. According to the simple regression analysis of indirect tests and UTS test; $R^{2}$ values are found for $3 P B S$ as 
0.79 in TS EN standard with dimensions $50 \times 50 \times 300 \mathrm{~mm}, 0.86$ in TS EN standard with dimensions $25 \times 50 \times 150 \mathrm{~mm}$ and 0.81 in ASTM standard. Moreover, $\mathrm{R}^{2}$ values are found for 4PBS as 0.81 in ASTM standard, 0.86 in TS EN standard with

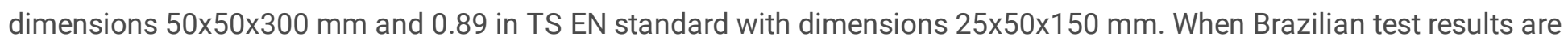
used in simple regression analysis for predicting UTS values, the $R^{2}$ value has been found as 0.87 in $t / D=1.0,0.82$ in $t / D$ $=0.75$ and 0.80 in $t / D=0.5$. However, according to multiple linear regression analysis, the best model with $R^{2}$ of 0.99 was found in combination of the Brazilian test results $(t / D=1.0)$ and $V_{p}$ values. The $R^{2}$ values found as a result of multiple regression analysis using indirect methods and $V_{p}$ test results were higher than the $R^{2}$ values obtained from the simple analysis results.

According to this study, the $V_{p}$ value was found to be the most suitable parameter to be used to estimate the UTS values of the rocks using indirect methods. The reason why $V_{p}$ tests of rocks are used in this study is to obtain more accurate information about various material properties such as porosity, degree of degradation, homogeneity, availability of discontinuities (cracks, joints) in the structure. With the help of empirical equations, corrected UTS values were calculated and compared with the results of UTS test. $R^{2}$ values were 0.987 for BTS, 0.926 for 3PBS and 0.928 for 4PBS, respectively. As a result of the study, it has been suggested that the best regression model for estimating the TS of rocks is that includes BTS and P-wave values. When the data obtained using the formulas (c-UTS) and the actual values obtained from the experimental results are compared, it is seen that the proposed models can be used in practice. However, similar studies including $V_{p}$ values for different materials will shed light on the usability of the proposed models.

\section{Declarations}

Acknowledgements This work was financially supported by The Scientific and Technological Research Council of Turkey (TUBITAK- Project Number: 116M724).

Conflict of interest The authors declare that they have no known competing financial interests or personal relationships that could have appeared to influence the work reported in this paper.

\section{References}

1. ASTM C880/C880M-15 (2015) Standard test method for flexural strength of dimension stone. ASTM International, West Conshohocken

2. ASTM C99/C99M-15 (2015) Standard test method for modulus of rupture of dimension stone. ASTM International, West Conshohocken

3. ASTM D2845-08 (2017) Standard test method for laboratory determination of pulse velocities and ultrasonic elastic constants of rock. ASTM International, West Conshohocken

4. ASTM D2936-08 (2008) Standard test method direct tensile strength of intact rock core specimens. ASTM International, West Conshohocken

5. ASTM D3967-08 (2008) Standard test method for splitting tensile strength of intact rock core specimens. ASTM International, West Conshohocken

6. Briševac Z, Kujundžić T, Čajić S (2015) Current cognition of rock tensile strength testing by Brazilian test. The MiningGeology-Petroleum Engineering Bulletin 30(2):101-114

7. Cetintas S, Akboga Z (2020) Investigation of resistance to ageing by SO2 on some building stone. Constr Build Mater 262:120341. https://doi.org/10.1016/j.conbuildmat.2020.120341 
8. Chen R, Stimpson B (1993) Interpretation of indirect tensile strength when moduli of deformation in compression and in tension are different. Rock Mech Rock Eng 26(2):183-189

9. Coviello A, Lagioia R, Nova R (2005) On the measurement of the tensile strength of soft rocks. Rock Mech Rock Eng $38(4): 251-273$

10. Efe T, Sengun N, Demirdag S, Tufekci K, Altindag R (2019) Effect of sample dimension on three and four points bending tests of fine crystalline marble and its relationship with direct tensile strength. World Multidisciplinary Earth Sciences Symposium (WMESS 2018), IOP Conf Ser: Earth Environ Sci 221(012093):1-12. doi:10.1088/1755$1315 / 221 / 1 / 012093$

11. Efe T, Demirdag S, Tufekci K, Sengun N, Altindag R (2021) Estimating the direct tensile strength of rocks from indirect tests. Arab J Geosci 14:1343. https://doi.org/10.1007/s12517-021-07539-9

12. Erarslan N, Williams DJ (2012) Investigating the effect of cyclic loading on the indirect tensile strength of rocks. Rock Mech Rock Eng 45(3):327-340

13. Fahimifar A, Malekpour M (2012) Experimental and numerical analysis of indirect and direct tensile strength using fracture mechanics concepts. Bull Eng Geol Environ 71:269-283

14. Fairhust C (1964) On the validity of the Brazilian test for brittle materials. Int J Rock Mech Min Sci Geomech Abstr 1(4):535-546

15. Garia S, Pal AK, Ravil K, Nair AM (2019) A comprehensive analysis on the relationships between elastic wave velocities and petrophysical properties of sedimentary rocks based on laboratory measurements. Journal of Petroleum Exploration Production Technology 9:1869-1881

16. Hobbs DW (1965) An assessment of a technique for determining the tensile strength of rock. Br J Appl Phys 16(2):259-268

17. Hoek E, Brown ET (1980) Emprical strength criterion for rock masses. J Geotech Eng Div 106(GT9):1013-1035

18. ISRM (1978) Suggested methods for determining tensile strength of rock materials. Int J Rock Mech Min Sci Geomech Abstr 15(3):99-103

19. ISRM (2007) The complete ISRM suggested methods for rock characterization, testing and monitoring: Suggested methods prepared by the commission on testing methods, Int Soc Rock Mech, Compilation Arranged by the ISRM Turkish National Group 1974-2006

20. Jaeger JC, Cook NGW, Zimmerman RW (2007) Fundamentals of rock mechanics (Fourth Edition). Blackwell Publishing, USA

21. Kahraman S, Fener M, Kozman E (2012) Predicting the compressive and tensile strength of rocks from indentation hardness index. J S Af I Min Metall 112(5):331-339

22. Karaca Z (2010) Water absorption and dehydration of natural stones versus time. Constr Build Mater 24:786-790

23. Komurlu E, Kesimal A, Durmus DA (2017) Dog bone shaped specimen testing method to evaluate tensile strength of rock materials. Geomech Eng 12(6):883-898

24. Li D, Wong LNY (2013) The Brazilian disc test for rock mechanics applications: Review and new insights. Rock Mech Rock Eng 46(2):269-287

25. Liu Y, Lu CP, Liu B, Zhang H, Wang HY (2019) Experimental and field investigations on seismic response of joints and beddings in rocks. Ultrasonics 97:46-56

26. Liu Z, Zhou H, Zhang W, Xie S, Shao J (2019) A new experimental method for tensile property study of quartz sandstone under confining pressure. Int J Rock Mech Min Sci 123:104091. https://doi.org/10.1016/j.ijrmms.2019.104091

27. Mahdiyar A, Armaghani DJ, Marto A, Nilashi M, Ismail S (2019) Rock tensile strength prediction using empirical and soft computing approaches. Bull Eng Geol Environ 78:4519-4531

Page $14 / 24$ 
28. Montgomery DC, Runger GC (2013) Applied statistics and probability for engineers (6th Edition). Wiley, USA

29. Moradian ZA, Behnia M (2009) Predicting the uniaxial compressive strength and static Young's modulus of intact sedimentary rocks using the ultrasonic test. Int J Geomech 9(1):14-19

30. Pandey P, Singh DP (1986) Deformation of a rock in different tensile tests. Eng Geol 22(3):281-292

31. Perras MA, Diederichs MS (2014) A review of the tensile strength of rock: Concepts and testing. Geotech Geological Eng 32(2):525-546

32. Raj K, Pedram R (2015) Correlations between direct and indirect strength test methods. Int J Min Sci Technol 25(3):355-360

33. Rio LM, Lo'pez F, Esteban FJ, Tejado JJ, Mota M, Gonza'lez I, San Emeterio JL, Ramos A (2006) Ultrasonic characterization of granites obtained from industrial quarries of Extremadura (Spain). Ultrasonics 44:e1057-e1061

34. Tang CA, Tham LG, Wang SH, Liu H, Li WH (2007) A numerical study of the influence of heterogeneity on the strength characterization of rock under uniaxial tension. Mech Mater 39:326-339

35. TS EN 1936 (2006) Natural stone test methods - Determination of real density and apparent density, and of total and open porosity. Turkish Standards Institution, Ankara/Turkey

36. TS EN 12372 (2007) Natural stone test methods-Determination of flexural strength under concentrated load. Turkish Standards Institution, Ankara/Turkey

37. TS EN 13161 (2014) Natural stone test methods-Determination of flexural strength under constant moment. Turkish Standards Institution, Ankara/Turkey

38. Unlu T, Yilmaz OA (2014) Development of a new push-pull direct tensile strength testing apparatus (PPTA). Geotech Test J 37(1):60-70

39. Uyanık O, Sabbag N, Uyanık NA, Oncu Z (2019) Prediction of mechanical and physical properties of some sedimentary rocks from ultrasonic velocities. Bulletin of Engineering Geology the Environment 78:6003-6016

40. Yagız S (2011) P-wave velocity test for assessment of geotechnical properties of some rock materials. Bull Mater Sci 34(4):947-953

41. Yates T, Richardson D, Miglio B (2012) Changes in engineering properties ofnatural stone. Proceedings of the Institution of Civil Engineers, Construction Materials 165 (2012) 127-133. http://dx.doi.org/10.1680/coma.9.00023

\section{Figures}




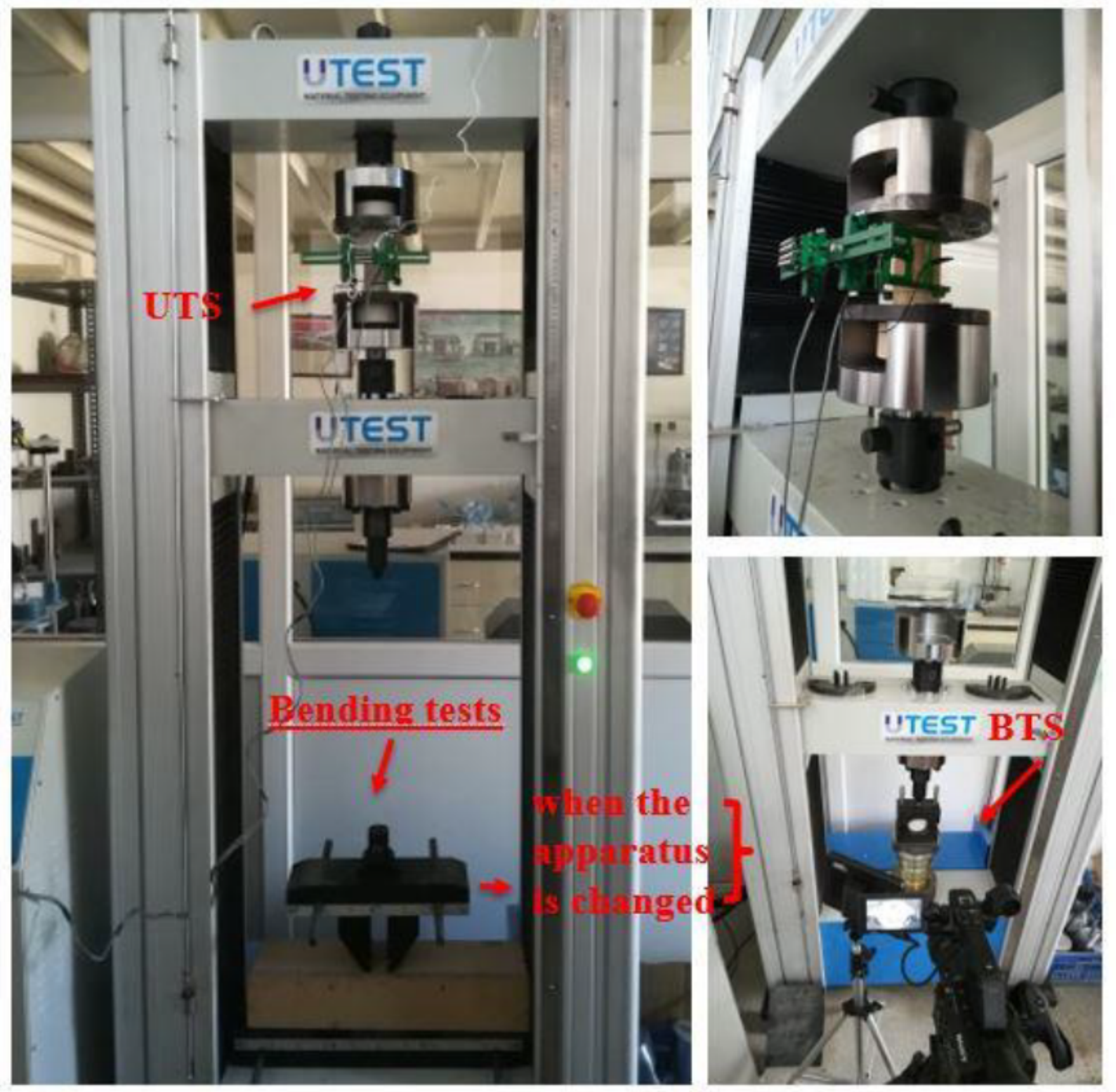

Figure 1

Universal electromechanical testing machine 

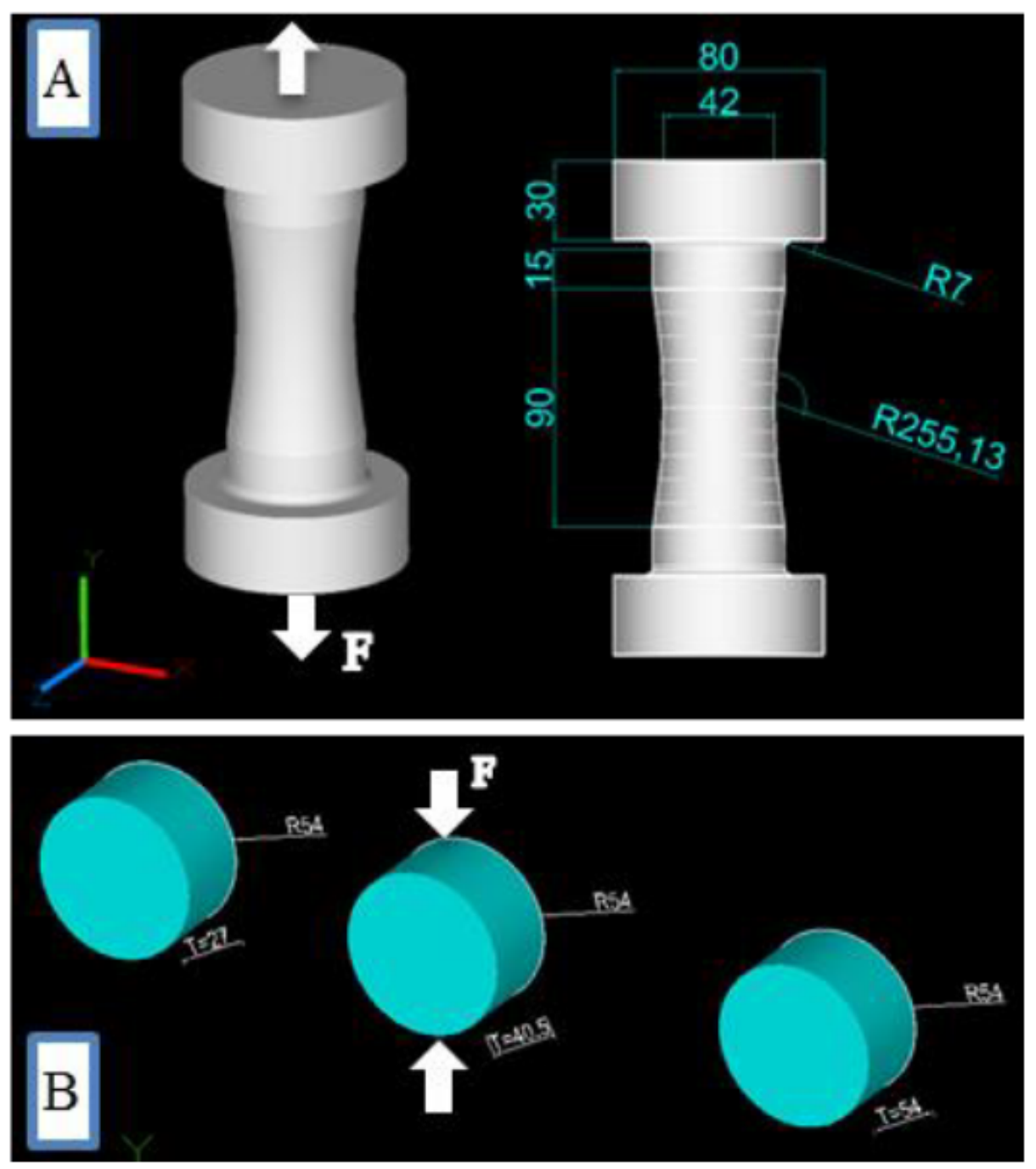

Figure 2

Drawings of direct and indirect tensile test samples (in $\mathrm{mm}$ ) (A) UTS test (B) BTS tests with 3 different thickness/diameter ratios 

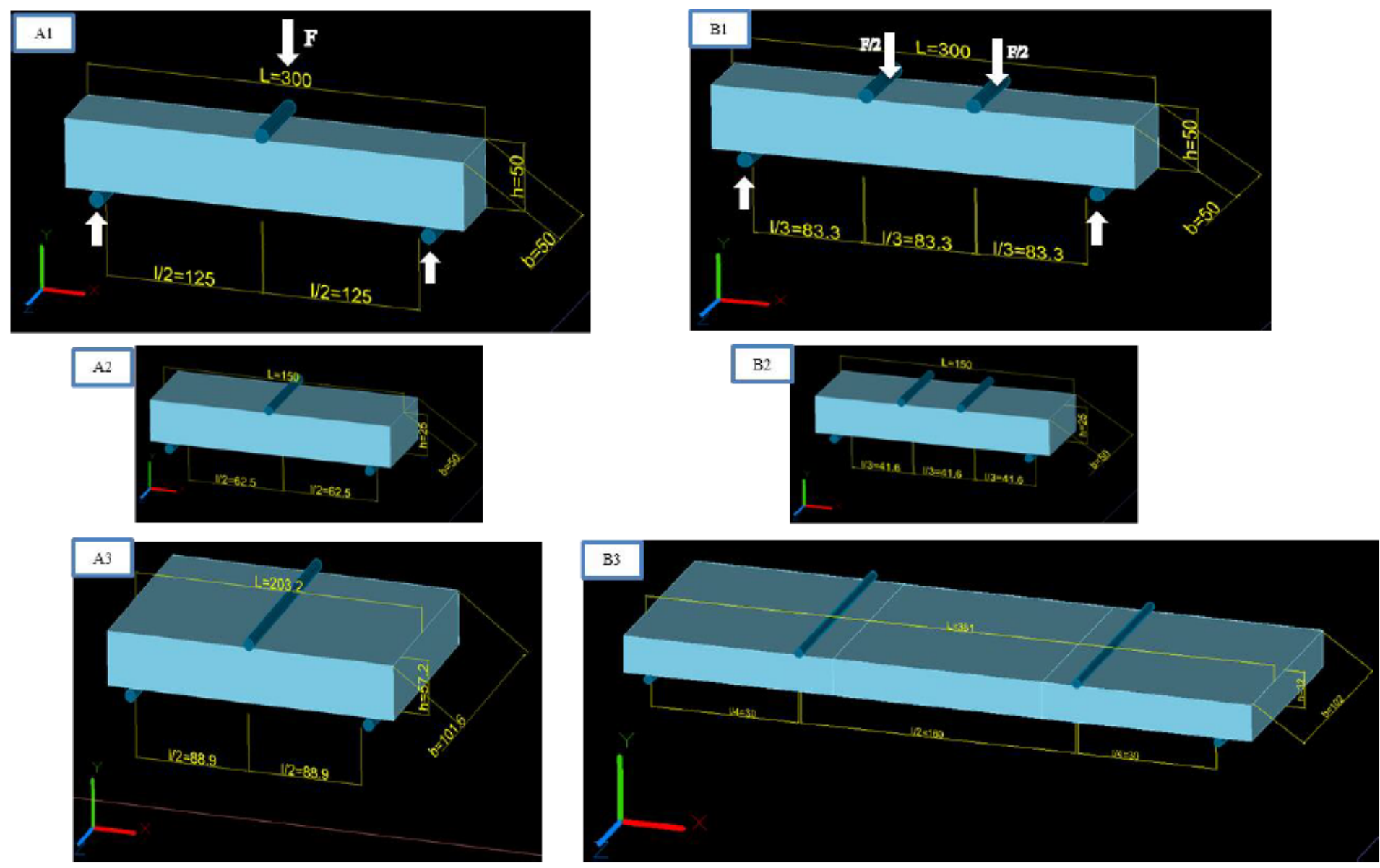

\section{Figure 3}

Drawings of bending test samples (A1) 3PBS test according to EN 12372 standard in dimensions of 50*50*300 mm (A2) 3PBS according to EN 12372 in dimensions of 25*50*150 mm (A3) 3PBS test according to ASTM C 99 (B1) 4PBS test according to EN 13161 standard in dimensions of 50*50*300 mm (B2) 4PBS test according to EN 13161 standard in dimensions of $25 * 50 * 150 \mathrm{~mm}$ (B3) 4PBS test according to ASTM $880-98$ 

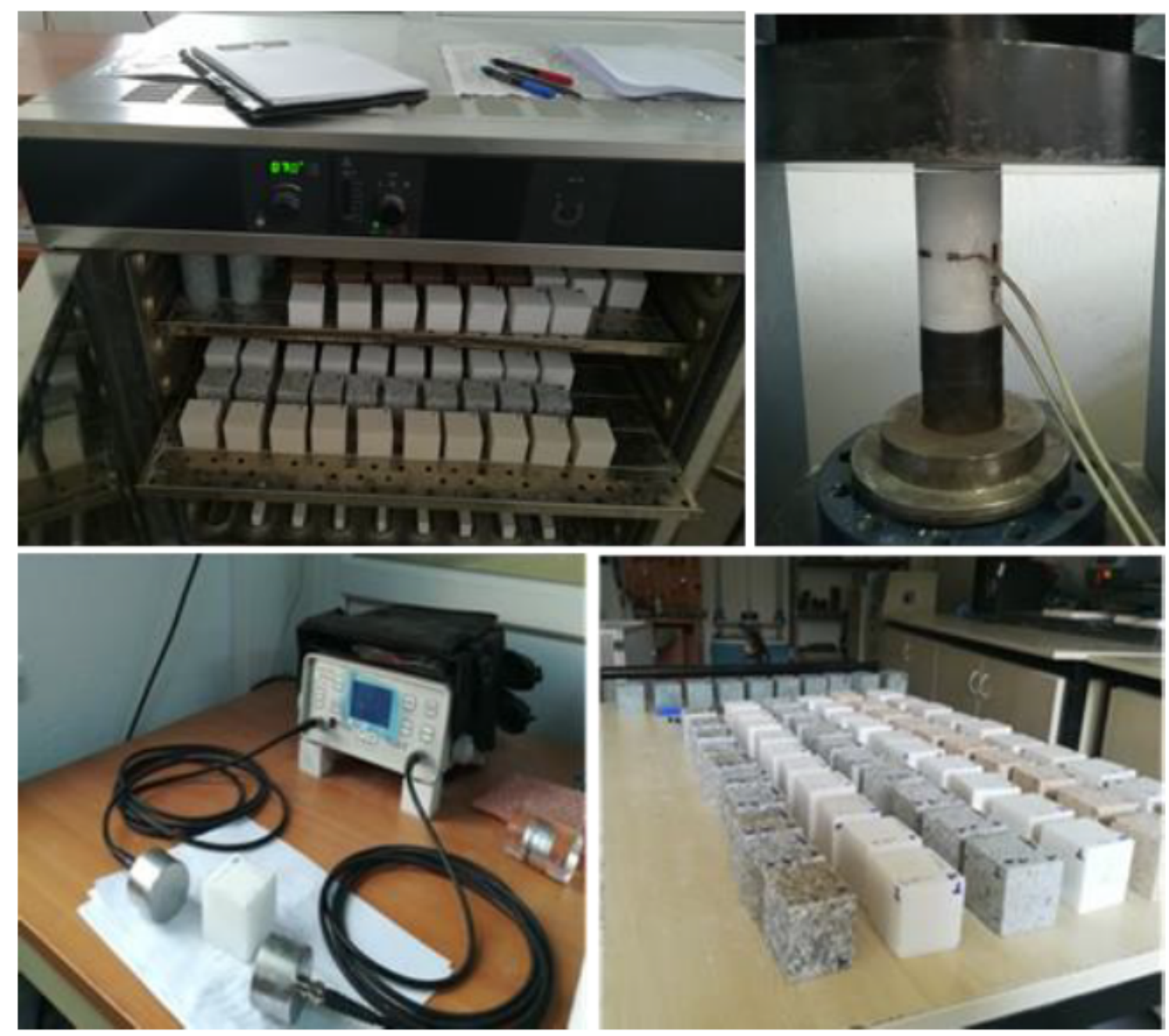

\section{Figure 4}

Tests of physical and mechanical properties 


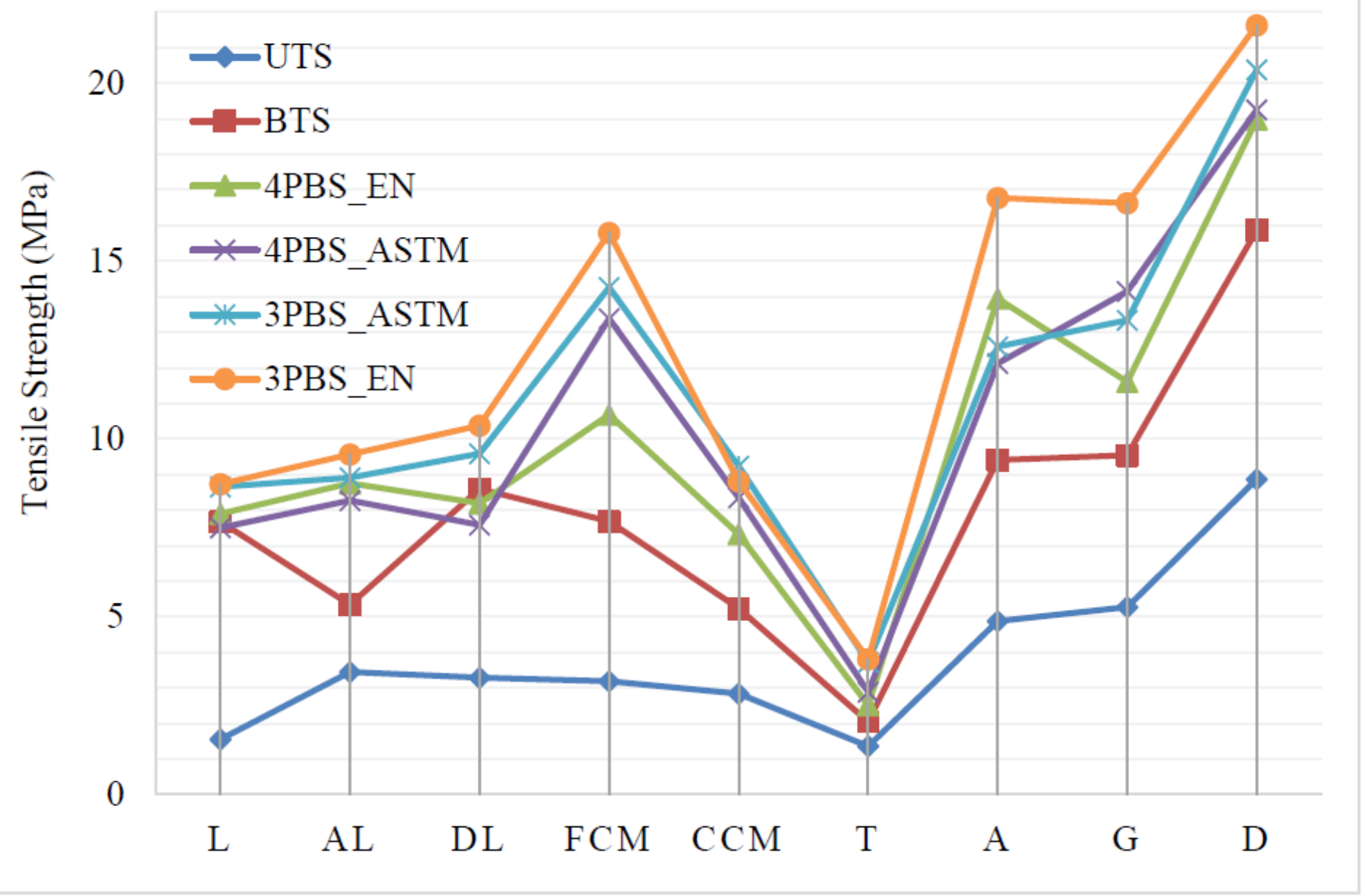

Figure 5

Comparison of direct and indirect tensile strength results 

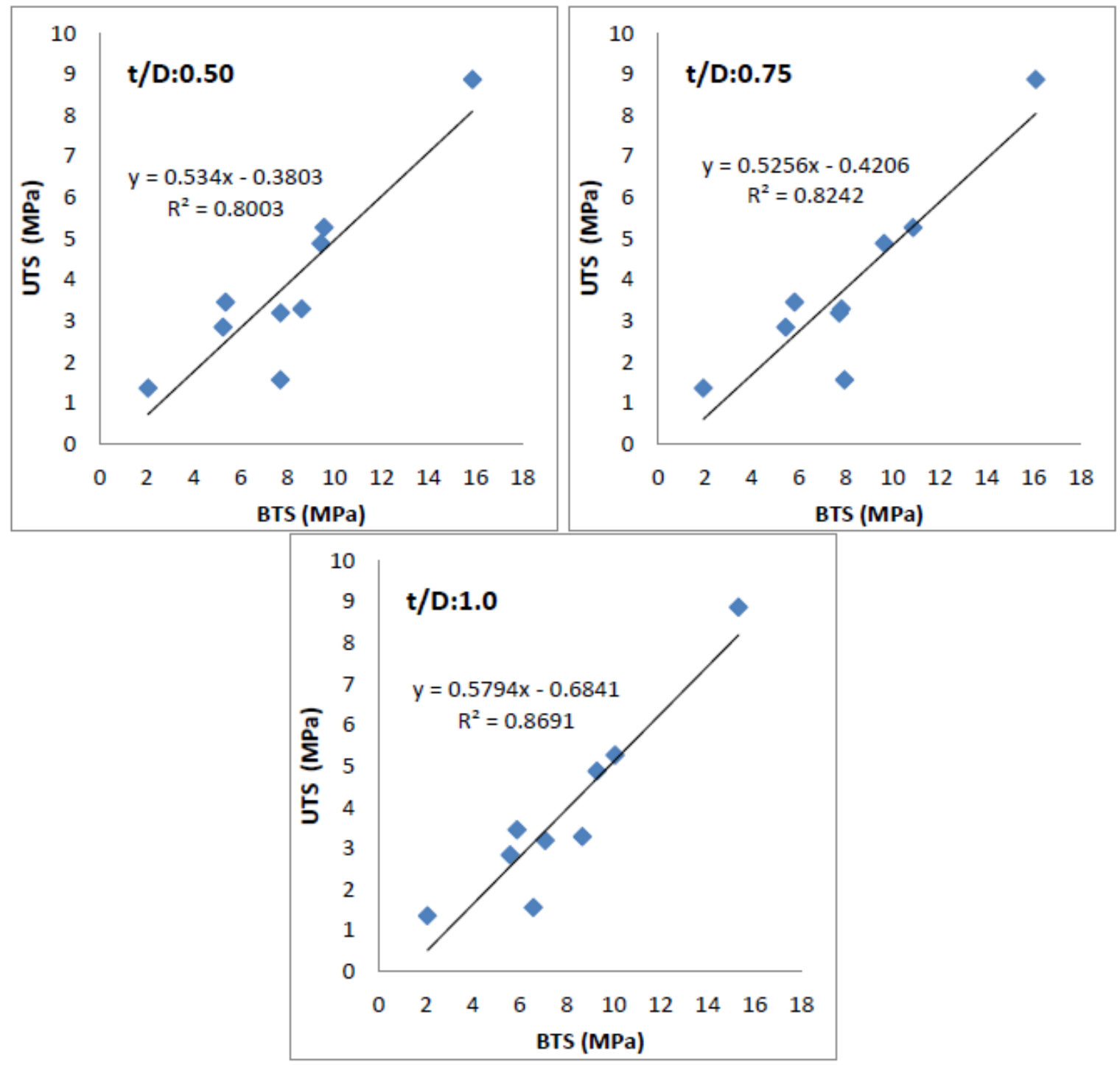

Figure 6

Simple linear regression analyses of BTS and UTS 


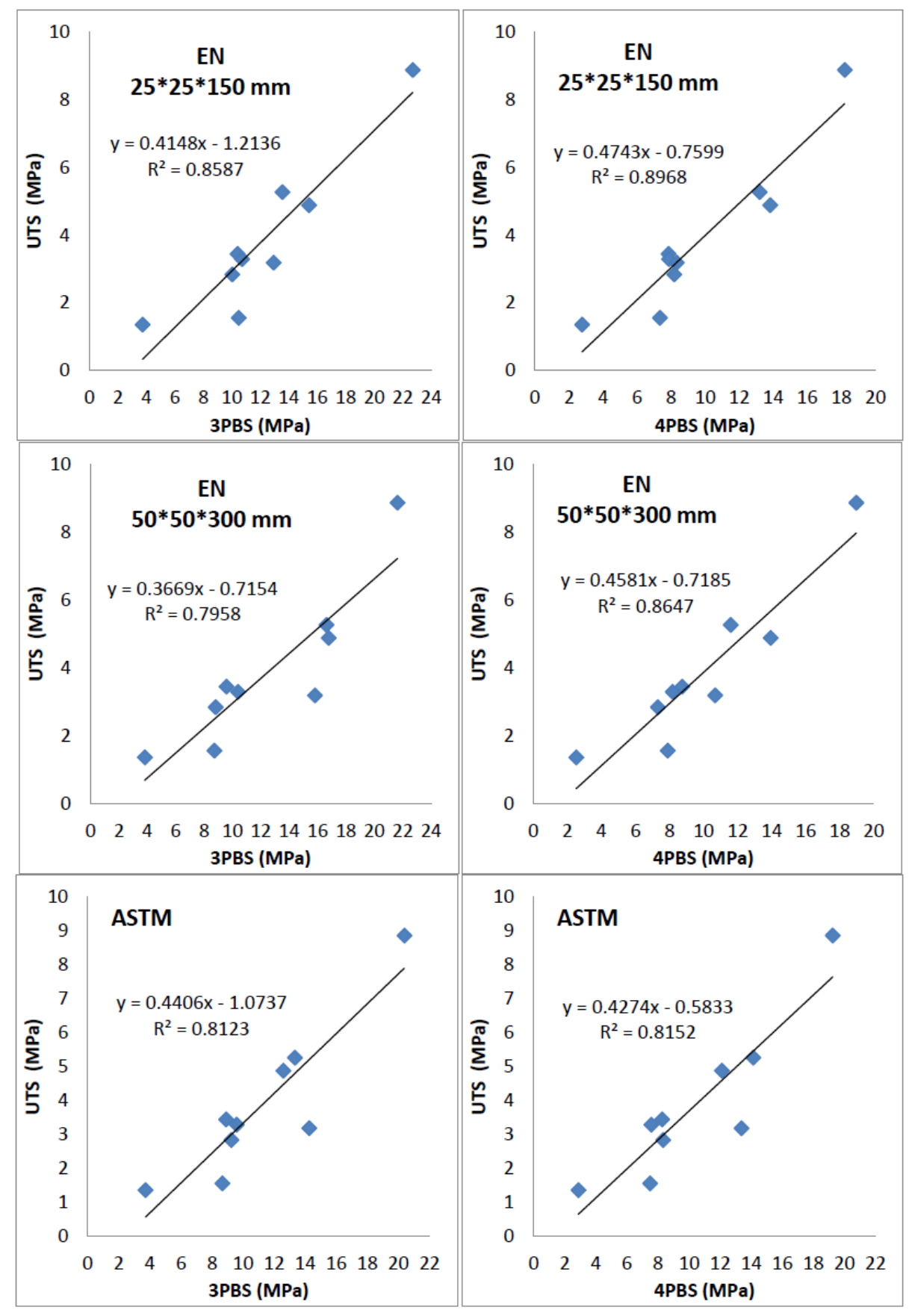

Figure 7

Simple linear regression analyses of Bending strength and UTS 


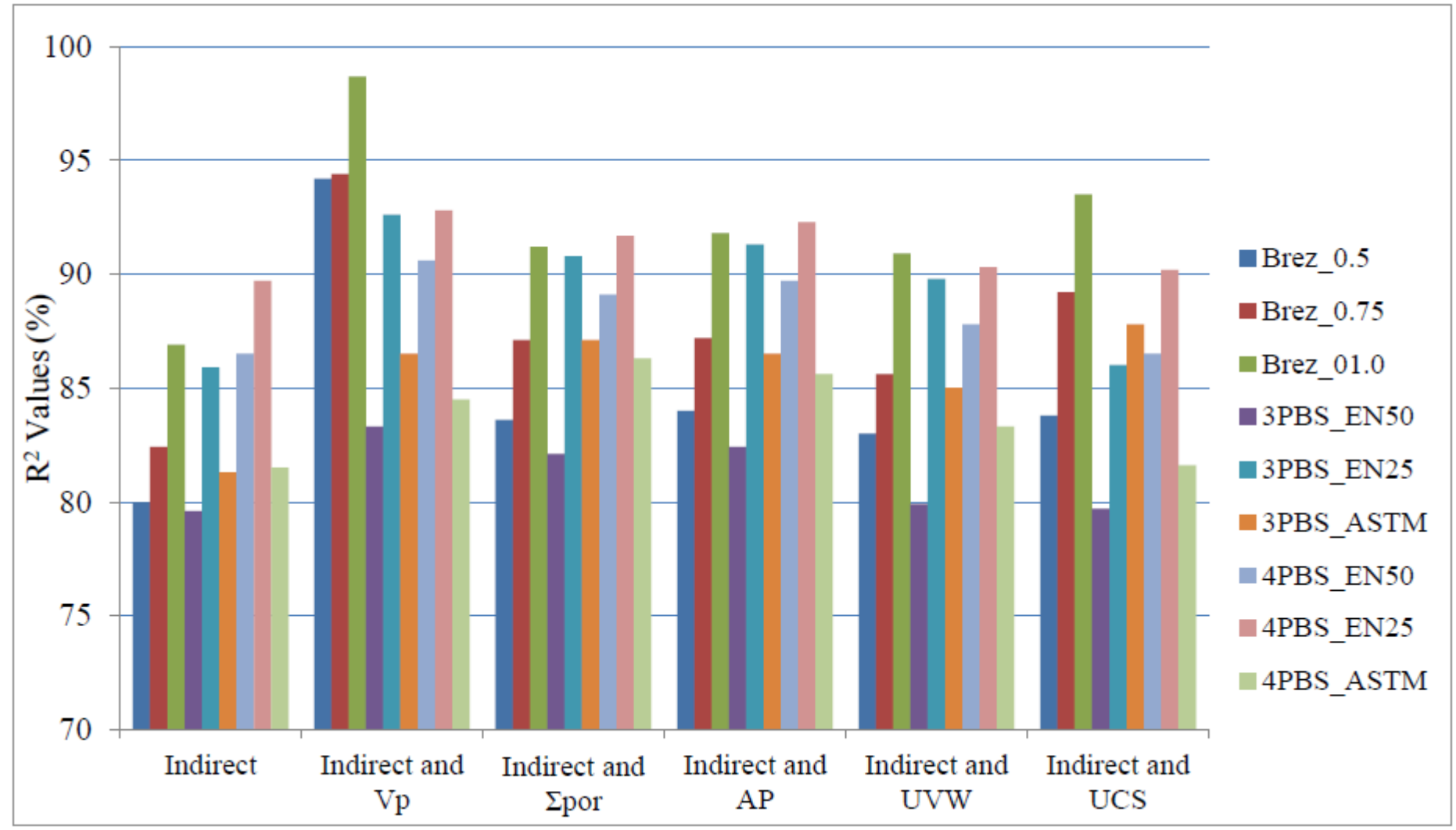

Figure 8

Comparison of $\mathrm{R} 2$ values 


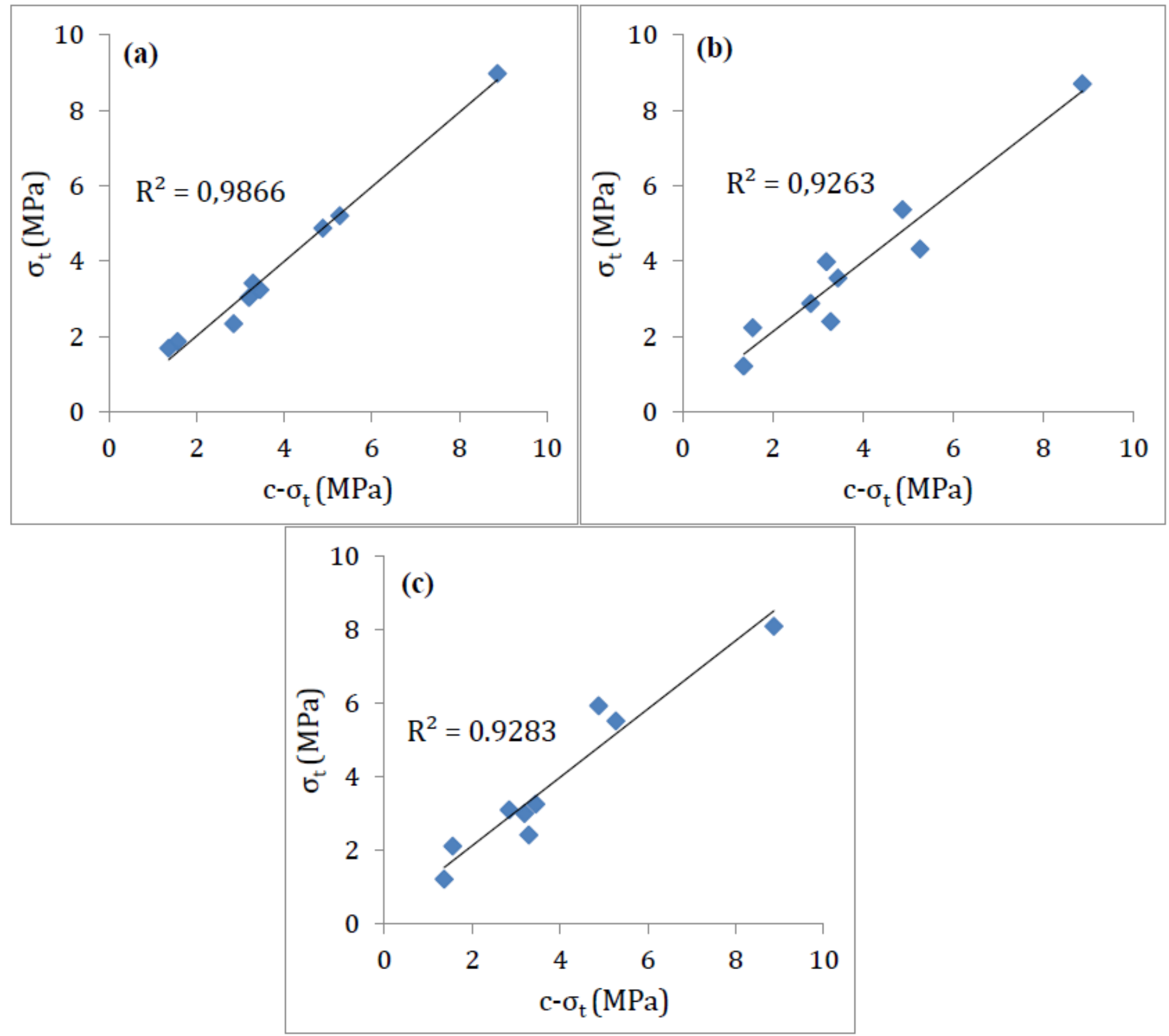

Figure 9

Relationship between UTS and corrected UTS: (a) for BTS test, (b) for 3PBS test, (c) for 4PBS test 